SUBJECT AREAS:

GEOCHEMISTRY

PHOTOSYNTHESIS

Received

2 December 2013

Accepted

10 September 2014

Published

7 October 2014

Correspondence and requests for materials should be addressed to J.Y. (yjhdzs@ies.ac.cn) \section{temperature on the $\mathrm{AMS}{ }^{14} \mathrm{C}$ dating of modern crop phytoliths}

Jinhui Yin ${ }^{1,2}$, Xue Yang ${ }^{1} \&$ Yonggang Zheng ${ }^{1}$

\begin{abstract}
'State Key Laboratory of Earthquake Dynamics, Institute of Geology, China Earthquake Administration, Beijing 100029, China, ${ }^{2}$ State Key Laboratory of Loess and Quaternary Geology, Institute of Earth Environment, Chinese Academy of Sciences, Xi'an 710075, China.
\end{abstract}

Several attempts have been made to directly date phytoliths, but most ${ }^{14} \mathrm{C}$ results are not consistent with other independent chronologies. Due to the limited dataset, there is not a clear explanation for these discrepancies. Herein, we report the ${ }^{14} \mathrm{C}$ ages of phytolith-occluded carbon (PhytOC) from contemporary rice and millet crops that were combusted at different temperatures to investigate the relationship between the combustion temperature and resulting ${ }^{14} \mathrm{C}$ age. Our results show that the ${ }^{14} \mathrm{C}$ age of PhytOC increases directly with combustion temperature (up to $1100^{\circ} \mathrm{C}$ ) and results in age overestimations of hundreds of years. Considerably older ages are observed at higher temperatures, suggesting that it may be possible to distinguish between two fractions of organic carbon in phytoliths: labile and recalcitrant carbon. These findings challenge the assumption that PhytOC is homogeneous, an assumption made by those who have previously attempted to directly date phytoliths using ${ }^{14} \mathrm{C}$. ice and millet are two staple food crops that have been cultivated in the Yellow and Yangtze River basins of China since the early Neolithic period ${ }^{1,2}$. There is some uncertainty regarding the origin and spread of these important crops across East Asia, particularly China, due to the lack of adequate evidence from crop remains in archaeological sites ${ }^{3-5}$. In these archaeological sites, with climates ranging from moist and warm to semi-arid, typically only charred plant remains survive for several millennia ${ }^{6,7}$. As an alternative to these scarce, charred plant remains, phytoliths (biogenetic opals formed in plants when roots absorb soluble silica) represent a potentially useful geochronometer ${ }^{8,9}$. When plants die and decay, phytoliths are released into the soil and sediment ${ }^{10,11}$. Phytoliths are extremely durable and can be preserved in large amounts in most archaeological sites, and in some situations, they can form well-defined strata ${ }^{12,13}$.

Organic carbon (PhytOC) is occluded during the formation of a phytolith and sometimes represents up to $2 \%$ of the dry weight of a plant ${ }^{14-17}$. The PhytOC contents of millet and rice have been estimated to be $1.36 \mathrm{mg} \mathrm{g}^{-1}$ and $2.8 \mathrm{mg} \mathrm{g}^{-1}$, respectively ${ }^{18,19}$. The small sample size required by accelerator mass spectrometry (AMS) allows for the analysis of $<500 \mu \mathrm{g}$ of carbon; therefore, only a handful of soil can provide a sufficient amount of phytoliths for radiocarbon analysis.

Over the past decades, there have been a few attempts to measure the ${ }^{14} \mathrm{C}$ age of fossil phytoliths ${ }^{8,10,13,20-22}$. However, most ${ }^{14} \mathrm{C}$ ages of phytoliths are not consistent with independent chronologies. These discrepancies have been attributed to preferential oxidation ${ }^{8}$, stratigraphic disturbances ${ }^{20}$, or sample extraction methods ${ }^{23-25}$. Moreover, some new ${ }^{14} \mathrm{C}$ analyses of PhytOC from phytolith concentrates extracted from living grass or bamboo reported ages of up to several thousand years older ${ }^{26,27}$. A clear explanation for these surprisingly older dates is still lacking due to the limited dataset and exploration of extraction protocols ${ }^{27,28}$.

One hypothesis suggests that there may be two possible components of photosynthetic and recalcitrant organic matter in phytoliths ${ }^{27}$. The exact influence of these two components of PhytOC on ${ }^{14} \mathrm{C}$ dating needs to be examined in detail because previous attempts to date ${ }^{14} \mathrm{C}$ PhytOC have focused on the total organic matter within the phytolith, and these attempts have clearly failed. In some cases, the combustion temperature can be used to separate heterogeneous mixtures of labile and refractory carbonaceous components, each of which may have a different apparent radiocarbon age $\mathrm{e}^{29-31}$. Recently, a more robust phytolith extraction protocol suitable for carbon isotopic analysis was reported $\mathrm{d}^{32}$, and we use this protocol to further investigate the potential source of PhytOC. In this study, phytoliths were isolated from two different species of modern crops (rice and millet) using a modified version of the recently published protocol ${ }^{32}$ and were then combusted with $\mathrm{CuO}$ powder at different temperatures 


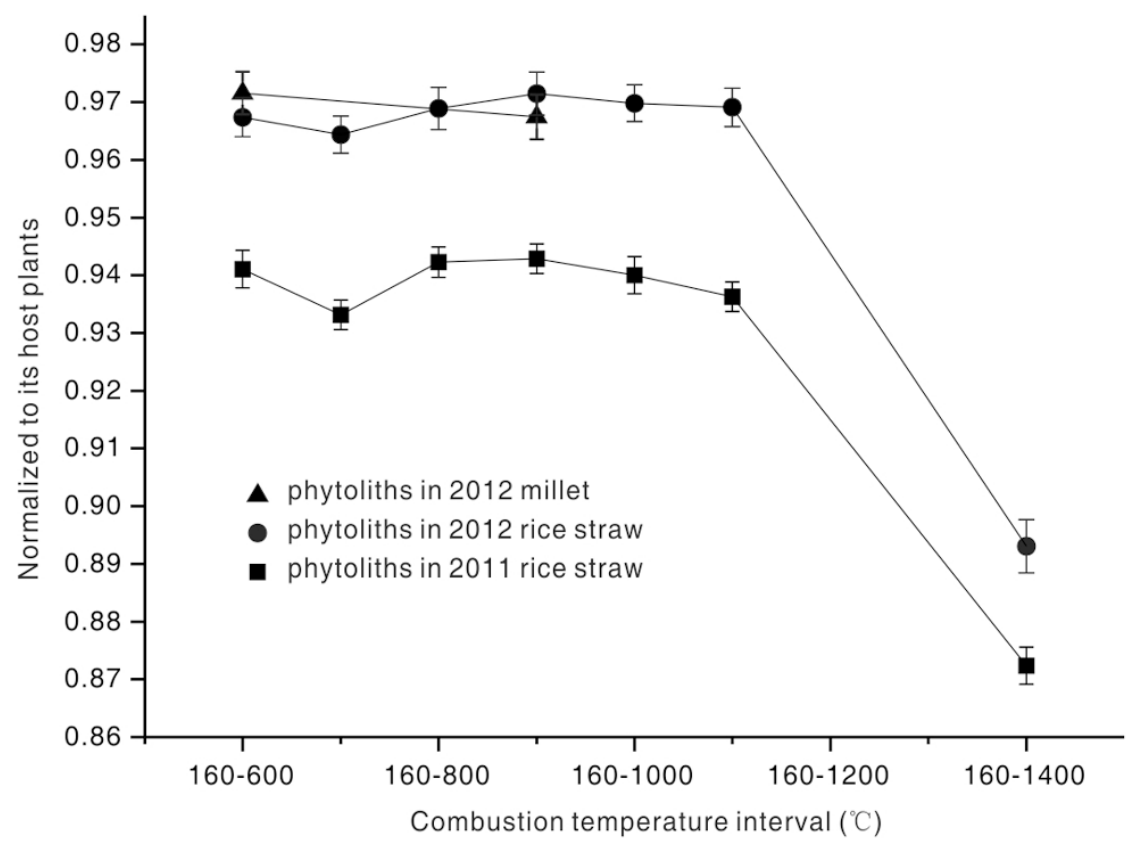

Figure 1 Variations of the AMS ${ }^{14} \mathrm{C}$ concentrations of phytoliths isolated from modern crop with increasing combustion temperature. Error bars represent the $68 \%( \pm 1 \sigma)$ range for overall analytical confidence.

ranging from $160^{\circ} \mathrm{C}$ to greater than $1400^{\circ} \mathrm{C}$. We analyse the ${ }^{14} \mathrm{C}$ and $\delta^{13} \mathrm{C}$ ratios produced by the range of combustion temperatures and compare them with the current atmospheric ratio to investigate the influence of combustion temperature on ${ }^{14} \mathrm{C}$ age. We explore these results in an attempt to delineate between the two hypothesised components of occluded organic carbon (PhytOC).

\section{Results}

Morphology of phytoliths. The extracted rice straw and millet phytoliths were examined using a scanning electron microscope (SEM) to ensure a lack of visible cellulose adhering to the outside of the phytoliths and to ensure the presence of intact samples with diameters of at least $20 \mu \mathrm{m}$ (Supplementary Figure S1). When the phytoliths were combusted with $\mathrm{CuO}$ to form $\mathrm{CO}_{2}$ gas, a manometer was used to monitor the production of $\mathrm{CO}_{2}$ as the temperature increased from $160^{\circ} \mathrm{C}$ to $900^{\circ} \mathrm{C}$. The combustion profiles of the phytolith samples show that the majority of $\mathrm{CO}_{2}$ is generated in two distinct temperature ranges: $500-600^{\circ} \mathrm{C}$ and $800-900^{\circ} \mathrm{C}$ (Supplementary Figure S2). This release pattern can be interpreted in terms of carbon being derived from a mixture of at least two components. As shown in Supplementary Figure S1, when the temperature reaches $900^{\circ} \mathrm{C}$, most phytoliths lose their distinct morphological characteristics, and when the samples are heated to $1100^{\circ} \mathrm{C}$, the phytoliths disappear.

${ }^{14} \mathrm{C}$ concentrations in the modern atmosphere. The AMS ${ }^{14} \mathrm{C}$ concentrations for modern crops and their phytolith samples, along with the $\delta^{13} \mathrm{C}$ values and carbon yield rates, are listed in Supplementary Table S1. The ${ }^{14} \mathrm{C}$ concentration in the atmosphere can be estimated from the three living crops. The modern fraction $\left(F_{m}\right.$, the deviation of the ${ }^{14} \mathrm{C} /{ }^{12} \mathrm{C}$ ratio of a sample from the ${ }^{14} \mathrm{C} /{ }^{12} \mathrm{C}$ ratio of "modern carbon") values from the direct AMS dating of the plant material for $\mathrm{AD} 2011$ rice straw, $\mathrm{AD} 2012$ rice straw and $\mathrm{AD} 2012$ millet are $1.0312 \pm 0.0028,1.0288 \pm 0.0027$, and $1.0223 \pm 0.0027$, respectively. These values are consistent with the atmospheric radiocarbon derived from the bomb radiocarbon curve in the Northern Hemisphere atmosphere ${ }^{33-35}$, suggesting that the ${ }^{14} \mathrm{C}$ in the plant is in equilibrium with the ${ }^{14} \mathrm{C}$ in the atmosphere.
${ }^{14} \mathrm{C}$ concentrations in phytoliths with increasing combustion temperature. The ${ }^{14} \mathrm{C}$ concentration in an individual phytolith sample was normalised to that in the host crop to more readily identify the deviation between the measured ${ }^{14} \mathrm{C}$ concentration in phytoliths and that measured for the atmosphere. We observe that the AMS ${ }^{14} \mathrm{C}$ concentrations in all 16 phytoliths are lower than those in the atmosphere (Figure 1).

We can confirm a ${ }^{14} \mathrm{C}$ depletion of several percent in PhytOC at combustion temperatures below $1100^{\circ} \mathrm{C}$ (Supplementary Table S1). For ${ }^{14} \mathrm{C}$ of phytoliths in $\mathrm{AD} 2011$ rice straw, a chi-square test was applied to compare the $F_{m}$ values of phytoliths combusted at temperatures below $1100^{\circ} \mathrm{C}$. The chi-square value of this dataset is 7.04 , which is less than 11.07 , the critical value for $95 \%$ confidence and 5 degrees of freedom, implying that the values are indistinguishable. The weighted mean for the $6 F_{m}$ values of phytoliths in AD 2011 rice straw is $0.9393 \pm 0.0013$. This ${ }^{14} \mathrm{C}$ level is $6 \%$ lower than the atmospheric concentration and corresponds to an apparent radiocarbon age of 480 yrs. Similarly, the $F_{m}$ values of PhytOC from AD 2012 rice straw ( $C_{3}$ plant) and AD 2012 millet $\left(C_{4}\right.$ plant) also passed the chisquare test. We obtain weighted means of $0.9684 \pm 0.0019$ and $0.9577 \pm 0.0013$, respectively. These results indicate that the deficiency in the ${ }^{14} \mathrm{C}$ content of the two samples is $3 \%$ to $4 \%$ lower when combusted at temperatures below $1100^{\circ} \mathrm{C}$, equivalent to ages of $250 \mathrm{yrs}$ and $320 \mathrm{yrs}$ older than the true ages of the plants, respectively.

In a further experiment, $0.5 \mathrm{~g}$ and $0.3 \mathrm{~g}$ of phytolith samples were sent to Beta Analytic Inc. to investigate PhytOC during higher-temperature combustions. The phytolith samples were combusted at temperatures greater than $1400^{\circ} \mathrm{C}$ via the exothermic reaction between tin and oxygen ${ }^{21}$. The two PhytOC samples combusted at temperatures above $1400^{\circ} \mathrm{C}$ produced $F_{m}$ values of $11 \%$ and $13 \%$ lower than those of the atmosphere, respectively, resulting in age estimates that were $\sim 1000$ yrs older than the true ages.

Similarly, the average $\delta^{13} \mathrm{C}$ values of PhytOC in AD 2011 rice straw and in $\mathrm{AD} 2012$ rice straw combusted at temperatures below $1100^{\circ} \mathrm{C}$ are $-33.66 \%$ and $-32.67 \%$, respectively (Supplementary Table S1). In contrast, when combusted at temperatures over $1400^{\circ} \mathrm{C}$, the $\delta^{13} \mathrm{C}$ values were $1.17 \%$ and $2.53 \%$ o heavier, respectively, than those of PhytOC combusted at the lower temperature. 
Background check. We also performed one ${ }^{14} \mathrm{C}$ determination on a phytolith assemblage isolated from $\mathrm{L}_{1-3}$ loess to evaluate the background value for this extraction procedure. The OSL age of $\mathrm{L}_{1-3}$ loess is approximately $71 \mathrm{ka} \mathrm{BP}$, which is beyond the limit of the radiocarbon dating method ${ }^{36}$. The $F_{m}$ value of phytoliths from $\mathrm{L}_{1-3}$ loess is $0.0051 \pm 0.0001$, corresponding to $42,380 \pm 180 \mathrm{yr} \mathrm{BP}$, which is statistically indistinguishable from the background of our AMS line background, which is equivalent to $42,750 \pm 190 \mathrm{yr}$ BP.

\section{Discussion}

If phytoliths are to become a new alternative candidate for ${ }^{14} \mathrm{C}$ dating for establishing a reliable age control for archaeological sites, the ${ }^{14} \mathrm{C}$ content in PhytOC must be in equilibrium with the ${ }^{14} \mathrm{C}$ content in the atmosphere when the organism dies. However, in this study, the most striking feature is that the ${ }^{14} \mathrm{C}$ contents in all 16 aliquots of phytoliths are lower than that in the atmosphere. These phytoliths were isolated from modern crops using a reliable, published protocol with only slight modifications. PhytOC accounted for $0.06-0.10 \%$ and $0.07 \%$ of the dry weight of rice and millet phytoliths, respectively (Supplementary Table S1), which is at least 20 times lower than the range of $14-34 \mathrm{mg} \mathrm{g}^{-1}$ for rice and $25.1 \mathrm{mg} \mathrm{g}^{-1}$ for millet ${ }^{18,19}$. These results indicate that the protocols used to extract phytoliths in this study are very harsh and can effectively eliminate possible sources of contamination during processing. We require $1200-2200 \mathrm{mg}$ of phytoliths to produce graphite samples with $\sim 0.8 \mathrm{mg}$ of carbon for AMS ${ }^{14} \mathrm{C}$ analysis. The precision and reproducibility of our experimental procedure, better than $0.3 \%$ for modern samples, could be evaluated by the mean $F_{m}$ value of the standard material oxalic acid II during AMS ${ }^{14} \mathrm{C}$ analysis. The background test of the phytolith extraction from $\mathrm{L}_{1-3}$ loess indicates that the protocols in our lab minimise the possibility of introducing contaminant carbon, specifically modern carbon, to the phytolith sample during extraction, graphitisation, and measurement. Moreover, the $6{ }^{14} \mathrm{C}$ overestimated ages (by hundreds of years) of phytolith samples with different weights from each rice crop are consistent when the samples are combusted at temperatures below $1100^{\circ} \mathrm{C}$. The average $\delta^{13} \mathrm{C}$ values of PhytOC also implies that a new carbonaceous compound with a heavier carbon isotope is liberated from phytoliths when combusted at temperatures greater than $1400^{\circ} \mathrm{C}$. Regardless, the change in the isotopic composition of PhytOC in rice straw cannot explain the systematic age offset. Therefore, this ${ }^{14} \mathrm{C}$ depletion in the phytoliths most likely originates from the temperature interval at which the sample itself was combusted. A similar trend has been described in other studies that used the same laboratory protocols ${ }^{27}$. In addition, this problem is not unique to our laboratory protocols because the AMS ${ }^{14} \mathrm{C}$ dates of phytoliths isolated from mature and recently senesced bamboo leaves using another separation method (microwave digestion) were inexplicably $3.5 \mathrm{ka}$ and $1.9 \mathrm{ka}$ too high, respectively ${ }^{28}$. These results clearly show a consistent shift in the ${ }^{14} \mathrm{C}$ levels when comparing phytoliths to modern plants regardless of their locations, species, and extraction methods. As mentioned above, for fossil phytoliths, most ${ }^{14} \mathrm{C}$ ages were inconsistent with expected or independent chronologies ${ }^{8,20,23,24,37}$. This problem could reveal that, even though the ${ }^{14} \mathrm{C}$ of the plant is in equilibrium with the atmosphere, the ${ }^{14} \mathrm{C}$ content of PhytOC is not.

Phytoliths can be changed by heating. Dry ashing has been widely used to recover phytoliths from plants since the beginning of phytolith analysis ${ }^{38}$. This method involves the incineration of plant tissue in muffled furnaces at temperatures of at least $500^{\circ} \mathrm{C}$. This technique has been suggested to cause shrinkage, warping and changes to the refractive index of phytoliths $s^{39,40}$. For rice crop phytoliths, it has been found that the original physical characteristics are significantly altered when the extraction temperature exceeds $900^{\circ} \mathrm{C}^{41}$. Previous studies indicated that the relationship between the ${ }^{14} \mathrm{C}$ age and combustion temperature can be used to quantify the relative contributions of different pools of organic carbon ${ }^{29-31}$. For phytoliths in AD
2012 rice straw, the $F_{m}$ of PhytOC was depleted by approximately $4 \%$ when the sample was combusted below $1100^{\circ} \mathrm{C}$ and was even more depleted (to approximately $12 \%$ ) when combusted over $1400^{\circ} \mathrm{C}$. We observe a similar trend between the combustion temperature and $F_{m}$ depletion of PhytOC in AD 2011 rice straw, suggesting that a mechanism may govern the ${ }^{14} \mathrm{C}$ variation with temperature. Our results indicate multiple carbon species, each of which may potentially have a unique ${ }^{14} \mathrm{C}$ concentration in phytoliths. One possible explanation is that there are two components of organic matter in phytoliths. The low-temperature pool (combusted below $900^{\circ} \mathrm{C}$ ) is associated with relatively labile carbon, whereas the high pool (combusted above $900^{\circ} \mathrm{C}$ ) is commonly associated with recalcitrant carbon.

We still have an incomplete understanding of PhytOC in phytoliths $s^{25,42-45}$. An early hypothesis suggested that recalcitrant PhytOC (biasing the ${ }^{14} \mathrm{C}$ results towards age overestimates) could be brought from the soil to the plant by root uptake ${ }^{27}$, but this hypothesis is still under debate ${ }^{28,46}$. We entertain another hypothesis to explain the discrepancies in the ${ }^{14} \mathrm{C}$ contents of our measured samples: two possible pools of ${ }^{14} \mathrm{C}$ exist in the phytoliths, each of which is attributed to a different type of phytolith development. Phytoliths are biogenetic opals that form in the cell walls, cell lumina and intercellular spaces of plants ${ }^{14,47,48}$. If biosilicification primarily occurs in the cell walls, hollow forms of phytoliths are formed and often contain cellular organelles such as mitochondria and plastids ${ }^{25,49}$. However, if biosilicification occurs in cell lumina or between cells, solid forms of phytoliths develop and contain mostly lipids and nucleic acids ${ }^{25,49}$. For sugar cane, the amount of PhytOC retained within hollow rather than solid phytoliths has been estimated to be $10.12 \%$ and $0.15 \%$, respectively ${ }^{50}$. These results suggest that, on average, the PhytOC from hollow phytolith cavities is 50 times more abundant than the PhytOC from solid phytoliths. Similar trends have also been observed in sorghum ${ }^{50}$. We also observe that organic materials are liberated from phytoliths in two distinct stages. For example, for rice straw from $\mathrm{AD} 2011$, the carbon yield rate was $0.07 \%$, and the $F_{m}$ value was $0.9363 \pm 0.0038$ when combusted below $1100^{\circ} \mathrm{C}$ (Supplementary Table S1). When combusted above $1400^{\circ} \mathrm{C}$, although the carbon yield rates did not change, the $F_{m}$ value was $0.8724 \pm 0.0046$. This $F_{m}$ value, attributed to the recalcitrant fraction of PhytOC, increased the apparent age of phytoliths even though the amount of recalcitrant carbon is minor compared to the total amount of carbon in the samples. The ratio of carbon released below $1100^{\circ} \mathrm{C}$ to that released above $1100^{\circ} \mathrm{C}$ during combustion can be estimated using a simple, two end-member mixing model. If one end-member is the ${ }^{14} \mathrm{C}$ released below $1100^{\circ} \mathrm{C}\left(F_{m}=0.9363 \pm 0.0038\right.$ for rice straw from $\mathrm{AD} 2011)$, then the other end-member is the ${ }^{14} \mathrm{C}$ released above $1100^{\circ} \mathrm{C}\left(F_{m}=0\right.$, dead carbon, no $\left.{ }^{14} \mathrm{C}\right)$; we calculate the ratio as 13 . Similarly, for AD 2012 rice straw, we calculate the ratio as 12 . Therefore, it is possible that the low-temperature carbon pool originates from hollow phytoliths formed in porous cell walls during photosynthesis. This carbon pool is more readily available for oxidation and lost from phytoliths at lower temperatures. Conversely, the high-temperature carbon pool may represent solid phytoliths formed in cell lumina. Further investigation of the mechanisms responsible for ${ }^{14} \mathrm{C}$ differentiation in the two fractions of PhytOC is necessary.

Therefore, we are working toward a new protocol that can successfully remove the recalcitrant carbon from phytoliths such that we can establish a reliable ${ }^{14} \mathrm{C}$ dating method for phytoliths. Among the many potential uses, a new protocol will allow us to better constrain the timing and origins of agriculture in East Asia.

\section{Methods}

Materials. Phytoliths were extracted from modern plants: two rice (Oryza sativa) stems (with leaves) and one millet (Panicum miliaceum). The dried rice straws were harvested from the Hubei province near the Yangtze River $\left(115^{\circ} \mathrm{E}, 30^{\circ} \mathrm{N}\right)$ in two successive years: AD 2011 and AD 2012. The millet was obtained from the Nihewan basin $\left(114^{\circ} \mathrm{E}, 40^{\circ} \mathrm{N}\right)$ in northwest Beijing in AD 2012. A fossil loess sample was 
collected from the Weinan section on the southeastern Chinese Loess Plateau and was dated by optically stimulated luminescence (OSL) to ca. $71 \mathrm{ka} \mathrm{BP}^{36}$.

Phytoliths isolated from modern crops and loess. Phytoliths were extracted from modern plants using a protocol involving both a sink-float specific gravity and a wetdigestion method detailed below (modified from a recently published protocol ${ }^{32}$ ). Approximately $700 \mathrm{~g}$ of each dried crop was used to obtain contemporary phytoliths. The rice straw samples were initially cut into $\mathrm{cm}$-sized pieces and immersed in a distilled $\mathrm{H}_{2} \mathrm{O}$ ultrasonic bath to remove any matter adhering to their surfaces. The sample was then immersed in $1 \mathrm{~N}$ hydrochloric acid $(\mathrm{HCl})$ for $4 \mathrm{~h}$ to eliminate carbonate material and stirred every half hour. The samples were washed three times in distilled $\mathrm{H}_{2} \mathrm{O}$ after the acid was decanted. The treated samples were dried in an oven at $70^{\circ} \mathrm{C}$ for three days. A $650 \mathrm{~g}$ aliquot of treated dry rice straw was weighed into a $4000 \mathrm{ml}$ beaker and digested with $\sim 5 \mathrm{ml}$ of concentrated $\mathrm{H}_{2} \mathrm{SO}_{4}$ per gram of dry plant material under a fume hood. The digestion lasted for $2 \mathrm{~h}$ at $70^{\circ} \mathrm{C}$, and the sample then sat unheated overnight. The following day, the hot plate was reheated to $70^{\circ} \mathrm{C}$, and hydrogen peroxide $\left(\mathrm{H}_{2} \mathrm{O}_{2}, 30 \%\right)$ was gradually added to destroy organic material until the liquid was clear and colourless. The supernatant liquid was poured off, and then the remains were rinsed 3 times with distilled water. The remaining solid material was then transferred into $100 \mathrm{ml}$ beakers and dried at $70^{\circ} \mathrm{C}$. After drying, we floated phytoliths using a heavy liquid $(\mathrm{KI}+\mathrm{HI}+\mathrm{Zn}$ ) with a specific gravity (sp.gr.) of $2.3^{51}$. The phytoliths were concentrated by centrifuging at $3000 \mathrm{rpm}$ for $30 \mathrm{~min}$. A few tiny dark minerals remained on the bottom of the cup after centrifugation. The liquid was then diluted with distilled water to a sp. gr. of 1.5. The supernatant liquid (with minimal organic matter) was poured off. This process was repeated three times. The recovered phytoliths were dried and retained.

After the phytoliths were recovered, they were washed and reheated at $70^{\circ} \mathrm{C}$ for $2 \mathrm{~h}$ in concentrated $\mathrm{HNO}_{3}$ and $\mathrm{NaClO}_{2}$ to ensure that any organic material clinging to the outer surfaces was removed. The sample sat unheated overnight, and the liquid was decanted. This step was repeated 4 times to maximise the oxidation of organic matter. The phytoliths were rinsed 3 times with distilled water and dried. Subsequently, they were immersed in a $0.001 \mathrm{M} \mathrm{NaOH}$ solution and heated at $70^{\circ} \mathrm{C}$ for $15 \mathrm{~min}$ to remove any alkali-soluble forms of organic matter. Afterward, the isolated phytoliths were washed again with concentrated $\mathrm{HNO}_{3}$ and rinsed 3 times with distilled water. Finally, phytolith concentrates were dried at $70^{\circ} \mathrm{C}$, weighed and observed with an optical microscope.

The background extraction method for phytoliths in loess is similar to the aforementioned method for modern plants. Sand grains larger than phytoliths were first removed by wet-sieving through an 80 -mesh screen and then added to $1 \mathrm{~N} \mathrm{HCl}$ to eliminate carbonates. Subsequently, two 50 -litre settling containers were used to separate the clays and organic colloids. The sedimentation-decanting procedure was repeated several times until the water was clear. The sample then was dried at $70^{\circ} \mathrm{C}$. The subsequent steps were the same as for the modern plants, but the extraction is usually repeated twice to increase phytolith recovery.

Cellulose extracted from modern crops. The radiocarbon content of cellulose separated from modern crops was used to represent the atmospheric ${ }^{14} \mathrm{CO}_{2}$ concentration. The crops were treated with sodium hydroxide at $70^{\circ} \mathrm{C}$ overnight. The alkali solution was refreshed until it remained clear, indicating that all soluble carbon had been removed. To yield alpha-cellulose, the sample was placed in a beaker and bleached with hot $\mathrm{NaClO}_{2} / \mathrm{HCl}$. This solution was heated to $70^{\circ} \mathrm{C}$. This bleaching procedure was repeated every 2 to $3 \mathrm{~h}$ until the sample appeared white. If the sample was not yet white, the bleaching procedure was repeated. After the straw had been satisfactorily bleached, it was rinsed with distilled water repeatedly and then dried in an oven at $70^{\circ} \mathrm{C}$

Measurements. Before isotope analyses, the phytolith morphologies were observed via SEM (a JSM-5800 equipped with an EDS system at the Beijing University of Aeronautics and Astronautics).

Approximately 1200 to $2200 \mathrm{mg}$ of phytolith samples was transferred into clean 9mm quartz tubes and combusted in a muffled furnace at $160^{\circ} \mathrm{C}$ overnight to release the carbon absorbed at the surface of phytoliths ${ }^{26}$. After the quartz tubes were cool, a measured amount of $\mathrm{CuO}$ powder and silver wire were added to the quartz tubes, and then they were connected to a graphite line and flame-sealed. PhytOC was combusted at temperature intervals ranging from $600^{\circ} \mathrm{C}$ to $1100^{\circ} \mathrm{C}$ to release $\mathrm{CO}_{2}$. Beyond $1000^{\circ} \mathrm{C}$, the phytolith sample was placed in a $6-\mathrm{mm}$ quartz tube and then enveloped in a 9-mm tube to avoid the rupture of the quartz tube during combustion. The $\mathrm{CO}_{2}$ was purified, and the volume of $\mathrm{CO}_{2}$ was measured. $\mathrm{CO}_{2}$ was then split, and a small portion of the sample was used to make a $\delta^{13} \mathrm{C}$ at the State Key Laboratory of Loess and Quaternary Geology, CAS, with a conventional isotope ratio mass spectrometer (except for cases in which an insufficient amount of $\mathrm{CO}_{2}$ was produced). Isotopic ratios in samples are expressed as per mil deviation relative to a VPDB standard with precision better than $0.2 \% \%^{52}$. The remaining $\mathrm{CO}_{2}$ was converted into graphite over iron at $550{ }^{\circ} \mathrm{C}$ in the presence of $\mathrm{H}_{2}{ }^{53}$. AMS ${ }^{14} \mathrm{C}$ dates were measured at $\mathrm{PKU}$ in a $0.5 \mathrm{MV}$ AMS and reported in $F_{m}$ values. The ${ }^{14} \mathrm{C}$ errors of each date include statistical uncertainties based on ${ }^{14} \mathrm{C}$ counts, standard and ${ }^{14} \mathrm{C}$ background targets, and machine random error ${ }^{54}$. The AMS ${ }^{14} \mathrm{C}$ dates are listed in Supplementary Table S1.

A series of standards run at the same time as the samples yielded the following values in agreement with the consensus values. The $F_{m}$ values of 6 targets from the first wheel were $1.3406 \pm 0.0042,1.3357 \pm 0.0024,1.3342 \pm 0.0028,1.3448 \pm 0.0044$, $1.3447 \pm 0.0032$, and $1.3442 \pm 0.0029$, with a weighted average $F_{m}$ of $1.3401 \pm$ 0.0007 . In addition, the $F_{m}$ values of 6 targets from the second wheel were $1.3427 \pm$
$0.0022,1.3388 \pm 0.0021,1.3406 \pm 0.0021,1.3439 \pm 0.0028,1.3424 \pm 0.0023$, and $1.3356 \pm 0.0022$, and the weighted mean $F_{m}$ can also be estimated to $1.3404 \pm 0.0006$ These results agree well with the consensus value of 1.3407 and demonstrate that the precision and reproducibility of our system are better than $0.3 \%$ for modern samples.

1. Lu, H. et al. Millet noodles in late Neolithic China. Nature 437, 967-968 (2005).

2. Zong, Y. et al. Fire and flood management of coastal swamp enabled first rice paddy cultivation in east China. Nature 449, 459-462 (2007).

3. Fuller, D. Q., Harvey, E. \& Qin, L. Presumed domestication? Evidence for wild rice cultivation and domestication in the fifth millennium BC of the Lower Yangtze region. Antiquity 81, 316-331 (2007).

4. Crawford, G. W. \& Shen, C. The origins of rice agriculture: recent progress in East Asia. Antiquity 72, 858-866 (1998).

5. Zhang, J. et al. Early Mixed Farming of Millet and Rice 7800 Years Ago in the Middle Yellow River Region, China. PLoS One 7, e52146 (2012).

6. Zhao, Z. New archaeobotanic data for the study of the origins of agriculture in China. Curr. Anthropol. 52, 295-306 (2011)

7. Atahan, P. et al. Holocene-aged sedimentary records of environmental changes and early agriculture in the lower Yangtze, China. Quaternary Sci. Rev. 27, 556-570 (2008).

8. Wilding, L. P. Radiocarbon dating of biogenetic opal. Science 156, 66-67 (1967).

9. Prasad, V., Stromberg, C. A. E., Alimohammadian, H. \& Sahni, A. Dinosaur coprolites and the early evolution of grasses and grazers. Science 310, 1177-1180 (2005).

10. Mulholland, S. C. \& Prior, C. [AMS radiocarbon dating of phytoliths] Current Research in Phytolith Analysis: Applications in Archaeology and Paleoecology, MASCA Research Papers in Science and Archaeology [Pearsall, D. M. \& Piperno, D. R. (eds.)] [21-23] (The University Museum of Archaeology and Anthropology, University of Pennsylvania, Philadelphia, 1993).

11. Parr, J. F. \& Sullivan, L. A. Soil carbon sequestration in phytoliths. Soil Biol. Biochem. 37, 117-124 (2005).

12. Albert, R. M. et al. Phytolith-rich layers from the Late Bronze and Iron Ages at Tel Dor (Israel): mode of formation and archaeological significance. J. Archaeol. Sci. 35, 57-75 (2008).

13. Piperno, D. R. Phytoliths: a comprehensive guide for archaeologists and paleoecologists. (AltaMira Press, Lanham MD, 2006).

14. Prychid, C. J., Rudall, P. J. \& Gregory, M. Systematics and biology of silica bodies in monocotyledons. Bot. Rev. 69, 377-440 (2003).

15. Jones, L. H. P., Milne, A. A. \& Wadham, S. M. Studies of silica in the oat plant. Plant Soil 18, 358-371 (1963).

16. Huang, Z.-T. et al. Long-term intensive management increased carbon occluded in phytolith (PhytOC) in bamboo forest soils. Sci. Rep. 4, 3602 (2014).

17. Li, Z., Song, Z. \& Li, B. The production and accumulation of phytolith-occluded carbon in Baiyangdian reed wetland of China. Appl. Geochem. 37, 117-124 (2013).

18. Zuo, X. \& Lü, H. Carbon sequestration within millet phytoliths from dry-farming of crops in China. Chinese Sci. Bull. 56, 3451-3456 (2011).

19. Li, Z., Song, Z., Parr, J. F. \& Wang, H. Occluded C in rice phytoliths: implications to biogeochemical carbon sequestration. Plant soil 370, 615-623 (2013).

20. Kelly, E. F., Amundson, R. G., Marino, B. D. \& Deniro, M. J. Stable isotope ratios of carbon in phytoliths as a quantitative method of monitoring vegetation and climate change. Quaternary Res. 35, 222-233 (1991).

21. Piperno, D. R. \& Stothert, K. E. Phytolith evidence for early Holocene Cucurbita domestication in southwest Ecuador. Science 299, 1054-1057 (2003).

22. McMichael, C. H. et al. Spatial and temporal scales of pre-Columbian disturbance associated with western Amazonian lakes. Holocene 22, 131-141 (2012).

23. Boaretto, E. Dating materials in good archaeological contexts: the next challenge for radiocarbon analysis. Radiocarbon 51, 275-281 (2009).

24. Prior, C. A., Carter, J. \& Rieser, U. Are phytolith radiocarbon dates reliable? the 10th International Conference on Accelerator Mass Spectrometry, Berkeley, USA. (http://lnl.confex.com/llnl/ams10/techprogram/P1592.HTM) (2005, September 5-10).

25. Carter, J. A. Atmospheric carbon isotope signatures in phytolith-occluded carbon. Quatern. Int. 193, 20-29 (2009).

26. Santos, G. M. et al. The phytolith ${ }^{14} \mathrm{C}$ puzzle: a tale of background determinations and accuracy tests. Radiocarbon 52, 113-128 (2010).

27. Santos, G. M. et al. Possible source of ancient carbon in phytolith concentrates from harvested grasses. Biogeosciences 9, 1873-1884 (2012).

28. Sullivan, L. A. \& Parr, J. F. Comment on:" Possible source of ancient carbon in phytolith concentrates from harvested grasses" by G. M. Santos et al.(2012). Biogeosciences 9, 13773-13782, doi:10.5194/bgd-9-13773-2012 (2012).

29. McGeehin, J. et al. Stepped-combustion ${ }^{14} \mathrm{C}$ dating of sediment: A comparison with established techniques. Radiocarbon 43, 255-261 (2001).

30. Kolic, E. D. Direct radiocarbon dating of pottery: Selective heat treatment to retrieve smoke-derived carbon. Radiocarbon 37, 275-284 (1995).

31. Hatté, C., Hodgins, G., Holliday, V. T. \& Jull, A. J. T. Dating Human Occupation on Diatom-Phytolith-Rich Sediment: Case Studies of Mustang Spring and Lubbock Lake, Texas, USA. Radiocarbon 52, 13-24 (2010).

32. Corbineau, R., Reyerson, P. E., Alexandre, A. \& Santos, G. M. Towards producing pure phytolith concentrates from plants that are suitable for carbon isotopic analysis. Rev. Palaeobot. Palyno. 197, 179-185 (2013). 
33. Levin, I. et al. Observations and modelling of the global distribution and longterm trend of atmospheric ${ }^{14} \mathrm{CO}_{2}$. Tellus B 62B, 26-46 (2010).

34. Graven, H. D., Guilderson, T. P. \& Keeling, R. F. Observations of radiocarbon in $\mathrm{CO}_{2}$ at La Jolla, California, USA 1992-2007: Analysis of the long-term trend. J. Geophys. Res. 117 (2012).

35. Hua, Q., Barbetti, M. \& Rakowski, A. Z. Atmospheric Radiocarbon for the Period 1950-2010. Radiocarbon 55, 2059-2072 (2013).

36. Kang, S., Lu, Y. \& Wang, X. Closely-spaced recuperated OSL dating of the last interglacial paleosol in the southeastern margin of the Chinese Loess Plateau. Quat. Geochronol. 6, 480-490 (2011).

37. McClaran, M. P. \& Umlauf, M. Desert grassland dynamics estimated from carbon isotopes in grass phytoliths and soil organic matter. J. Veg. Sci. 11, 71-76 (2000).

38. Rovner, I. [Plant opal phytolith analysis: major advances in archaeobotanical research] Advances in archaeological method and theory [Schiffer, M. B. (ed.)] [225-266] (Academic Press, New York, 1983).

39. Elbaum, R., Weiner, S., Albert, R. M. \& Elbaum, M. Detection of burning of plant materials in the archaeological record by changes in the refractive indices of siliceous phytoliths. J. Archaeol. Sci. 30, 217-226 (2003).

40. Parr, J. F., Lentfer, C. J. \& Boyd, W. E. A comparative analysis of wet and dry ashing techniques for the extraction of phytoliths from plant material. J. Archaeol. Sci. 28, 875-886 (2001).

41. Wu, Y., Wang, C. \& Hill, D. V. The transformation of phytolith morphology as the result of their exposure to high temperature. Microsc. Res. Techniq. 75, 852-855 (2012).

42. Pironon, J. et al. [Individual characterization of phytoliths: experimental approach and consequences on paleoenvironment understanding] Phytoliths:Applications in Earth Science and Human History [Meunier, J. D. \& Colin, F. (eds.)] [329-341] (A.A. Balkema Publishers, Lisse, 2001).

43. Smith, F. A. \& Anderson, K. B. [Characterization of organic compounds in phytoliths: Improving the resolving power of phytolith $\delta^{13} \mathrm{C}$ as a tool for paleoecological reconstruction of C3 and C4 grasses] Phytoliths: applications in earth sciences and human history [Meunier, J. D. \& Colin, F. (eds.)] [317-327] (A.A. Balkema Publishers, Lisse, 2001).

44. Perry, C. C., Williams, R. J. P. \& Fry, S. C. Cell wall biosynthesis during silicification of grass hairs. J. Plant Physiol. 126, 437-448 (1987).

45. Elbaum, R., Melamed-Bessudo, C., Tuross, N., Levy, A. A. \& Weiner, S. New methods to isolate organic materials from silicified phytoliths reveal fragmented glycoproteins but no DNA. Quatern. Int. 193, 11-19 (2009).

46. Evett, R. Interactive comment on "Comment on: "Possible source of ancient carbon in phytolith concentrates from harvested grasses" by G. M. Santos et al.(2012)" by L. A. Sullivan and J. F. Parr. http://www.biogeosciences-discuss. net/9/C6286/2012/ (2012) Date of access: 5 December 2012.

47. Song, Z., Wang, H., Strong, P. J., Li, Z. \& Jiang, P. Plant impact on the coupled terrestrial biogeochemical cycles of silicon and carbon: Implications for biogeochemical carbon sequestration. Earth-Sci. Rev. 115, 319-331 (2012).

48. Piperno, D. R. Phytolith analysis: an archaeological and geological perspective. (Academic Press, San Diego, 1988).

49. Hodson, M. Interactive comment on "Comment on: "Possible source of ancient carbon in phytolith concentrates from harvested grasses" by G. M. Santos et al.
(2012)" by L. A. Sullivan and J. F. Parr. http://www.biogeosciences-discuss.net/9/ C5612/2012/ (2012) Date of access: 12 November 2012.

50. Parr, J. F. \& Sullivan, L. A. Comparison of two methods for the isolation of phytolith occluded carbon from plant material. Plant Soil 374, 45-53 (2014)

51. Wang, Y. \& Lü, H. The study of phytolith and its application (in Chinese). (China Ocean Press, Beijing, 1993).

52. Liu, W., An, Z., Zhou, W., M, J., H \& Cai, D. Carbon isotope and C/N ratios of suspended matter in rivers: an indicator of seasonal change in $\mathrm{C}_{4 /} \mathrm{C}_{3}$ vegetation. Appl. Geochem. 18, 1241-1249 (2003).

53. Vogel, J. S., Southon, J. R., Nelson, D. E. \& Brown, T. A. Performance of catalytically condensed carbon for use in accelerator mass spectrometry. Nucl. Instrum. Meth. B 5, 289-293 (1984).

54. Liu, K. et al. A new compact AMS system at Peking University. Nucl. Instrum. Meth. B 259, 23-26 (2007).

\section{Acknowledgments}

This work was jointly supported by State Key Laboratory of Earthquake Dynamics (Project No. LED2013A08) and the fundamental scientific research special project of Institute of Geology, China Earthquake Administration (No: IGCEA-1116), and State Key Laboratory of Loess and Quaternary Geology, Institute of Earth Environment, CAS(SKLLQG0707). We are especially indebted to the technical support of the staff in PKUAMS center for their assistance and patient accommodation of our many AMS measurement requests.

\section{Author contributions}

J. Y. conceived the study, phytolith extraction, data interpretation, and wrote the manuscript. X. Y. performed the ${ }^{14} \mathrm{C}$ graphite and discussion of the results. Y. Z. assigned sample collection and sample pre-clean.

\section{Additional information}

Supplementary information accompanies this paper at http://www.nature.com/ scientificreports

Competing financial interests: The authors declare no competing financial interests.

How to cite this article: Yin, J., Yang, X. \& Zheng, Y. Influence of increasing combustion temperature on the AMS ${ }^{14} \mathrm{C}$ dating of modern crop phytoliths. Sci. Rep. 4, 6511; DOI:10.1038/srep06511 (2014)

This work is licensed under a Creative Commons Attribution-NonCommercialNoDerivs 4.0 International License. The images or other third party material in this article are included in the article's Creative Commons license, unless indicated otherwise in the credit line; if the material is not included under the Creative Commons license, users will need to obtain permission from the license holder in order to reproduce the material. To view a copy of this license, visit http:// creativecommons.org/licenses/by-nc-nd/4.0/ 